\title{
Geogene Versus Anthropogene Origin of Trace Metals in Sediments in Cua Luc Estuary and Ha Long Bay, Vietnam
}

\author{
Huu Hieu Ho • Rudy Swennen • Valérie Cappuyns • \\ Elvira Vassilieva • Gerda Neyens • Mustafa Rajabali • \\ Tan Van Tran
}

Received: 30 April 2012 / Revised: 24 September 2012 / Accepted: 30 September 2012 / Published online: 12 October 2012

(C) Coastal and Estuarine Research Federation 2012

\begin{abstract}
In the present study, the geochemistry of 49 surficial-bed and 101 core sediment samples is investigated to clarify the origin of trace metals in the Cua Luc Estuary and Ha Long Bay, which is a famous World Natural Heritage Site in Vietnam. Moreover, the potential mobility of trace metals is also assessed and their relationship with reference elements $(\mathrm{Al}, \mathrm{Fe}$, and $\mathrm{Ca})$ and organic matter is established in order to make recommendations for sediment management and monitor future pollution. Generally, trace metals display higher concentrations in Ha Long Bay compared to the Cua Luc Estuary. However, this is controlled by the distribution of the fine (clay+silt) fraction, and hence the concentrations of $\mathrm{Al}, \mathrm{Fe}, \mathrm{Ca}$, and organic matter $(\mathrm{OM})$. The comparison of concentrations of trace metals (normalized towards $\mathrm{Al}$ ) between the surficial sediments and the subsurface core sediments based on ${ }^{137} \mathrm{Cs}$ datings indicates that almost all surficial-sediment data fall inside or deviate slightly from the $95 \%$ prediction interval of a background
\end{abstract}

\footnotetext{
H. H. Ho $\cdot$ R. Swennen $\cdot$ V. Cappuyns $\cdot$ E. Vassilieva Geology, Department of Earth and Environmental Sciences, KU Leuven,

Heverlee-Leuven, Belgium

G. Neyens $\cdot$ M. Rajabali

Instituut voor Kern-en Stralingsfysica, KU Leuven,

Heverlee-Leuven, Belgium

\section{Cappuyns}

Center for Economics and Corporate Sustainability, Hogeschool-Universiteit Brussel,

Brussels, Belgium

H. H. Ho $(\bowtie) \cdot$ T. V. Tran

Vietnam Institute of Geosciences and Mineral Resources (VIGMR),

Hanoi, Vietnam

e-mail: hohuuhieu@yahoo.com
}

regression line. In addition, as determined by a Community Bureau of Reference three-step extraction, trace metals mainly dominate in the residual fraction (assumed to relate to crystal lattice of primary and secondary minerals), and this fraction does not change much in recent sediment layers. Therefore, trace metals are supposed to be derived from natural bio/geochemical processes and are characterized by a low potential mobility. Consequently, the established linear regression relationships of trace metal vs. Al or multiple regression relationships of trace metal vs. multielements $(\mathrm{Al}, \mathrm{Fe}, \mathrm{Ca}$, and $\mathrm{OM})$ are useful for the prediction of background levels of trace metals in sediments in future pollution monitoring and assessment programs.

Keywords Trace metal · Sediment · Origin · Mobility · Background level

\section{Introduction}

Trace metals are natural components of the geosphere, atmosphere, hydrosphere, and biosphere, and are present in varying amounts in all of the environment media surrounding man (Thornton 1995). In the sediment, their concentrations are derived naturally from the weathering and erosion processes of parent bedrocks. However, a significant proportion of them also arise as a result of man's activities (Thornton 1995; De Saedeleer et al. 2010). Spatial distribution of background concentrations of trace metals in sediments is a function of the grain size and mineralogy of the original sediment sources (Huisman et al. 1997). Therefore, when studying the origin of trace metals in sediments or assessing the contamination by anthropogenic activities, the relationships of trace metals with sediment properties such as organic matter content and grain size [e.g., clay $(\Phi<2 \mu \mathrm{m})$ or fine 
$(\Phi<63 \mu \mathrm{m})$ fraction] or with major element concentrations $(\mathrm{Al}, \mathrm{K}, \mathrm{Fe}, \mathrm{Ca}$, and $\mathrm{Mg}$ ) are normally considered (Huisman et al. 1997; Alagarsamy and Zhang 2010; De Saedeleer et al. 2010; Szarek-Gwiazda et al. 2011).

In sediments, trace metals can be bound to different reactive components that are contained in the particles (Jerald 1995). They can exist as discrete minerals or be absorbed and/or co-precipitated on clay minerals, organic matter, $\mathrm{Fe}$ and $\mathrm{Mn}$ hydr/oxides, carbonates, and sulfides. Remobilization of trace metals in these forms can occur as a result of changing environmental condition (e.g., $\mathrm{pH}$ and Eh). In addition, trace metals may also be present in crystal lattices of primary minerals and many secondary minerals. It is relevant to point out that trace metals under the latter form are relatively insoluble under the conditions normally encountered in natural soils and waters and unlikely to be released (Thornton 1995; Zerbe et al. 1999).

In this study, the geochemistry of surficial-bed and core sediments is investigated in the Cua Luc Estuary and $\mathrm{Ha}$ Long Bay, a famous landscape in Northeastern Vietnam which has been approved by UNESCO as a World Natural Heritage Site. The main objectives are (1) to understand the spatial distribution of trace metals in surficial sediments, (2) to establish models for the relationships of trace metals with sediment properties and assess the contribution from natural and anthropogenic sources, and (3) to evaluate the mobility of trace metals in the sediments.

\section{Materials and Methods}

\section{Description of the Study Area}

Ha Long Bay, approximately $1,553 \mathrm{~km}^{2}$ in size, consists of about 2,000 small islands located in Quang Ninh province (north-eastern Vietnam). Cua Luc Estuary is the area where the freshwaters from three rivers (Dien Vong, Man, and Troi) meet each other before entering Ha Long Bay (Fig. 1). Those rivers are short, steep, and small with a length between 15 and $35 \mathrm{~km}$ and a catchment area of less

$106^{\circ} 55^{\prime} 52^{\prime \prime} \mathrm{E}$

107¹0’29’'E

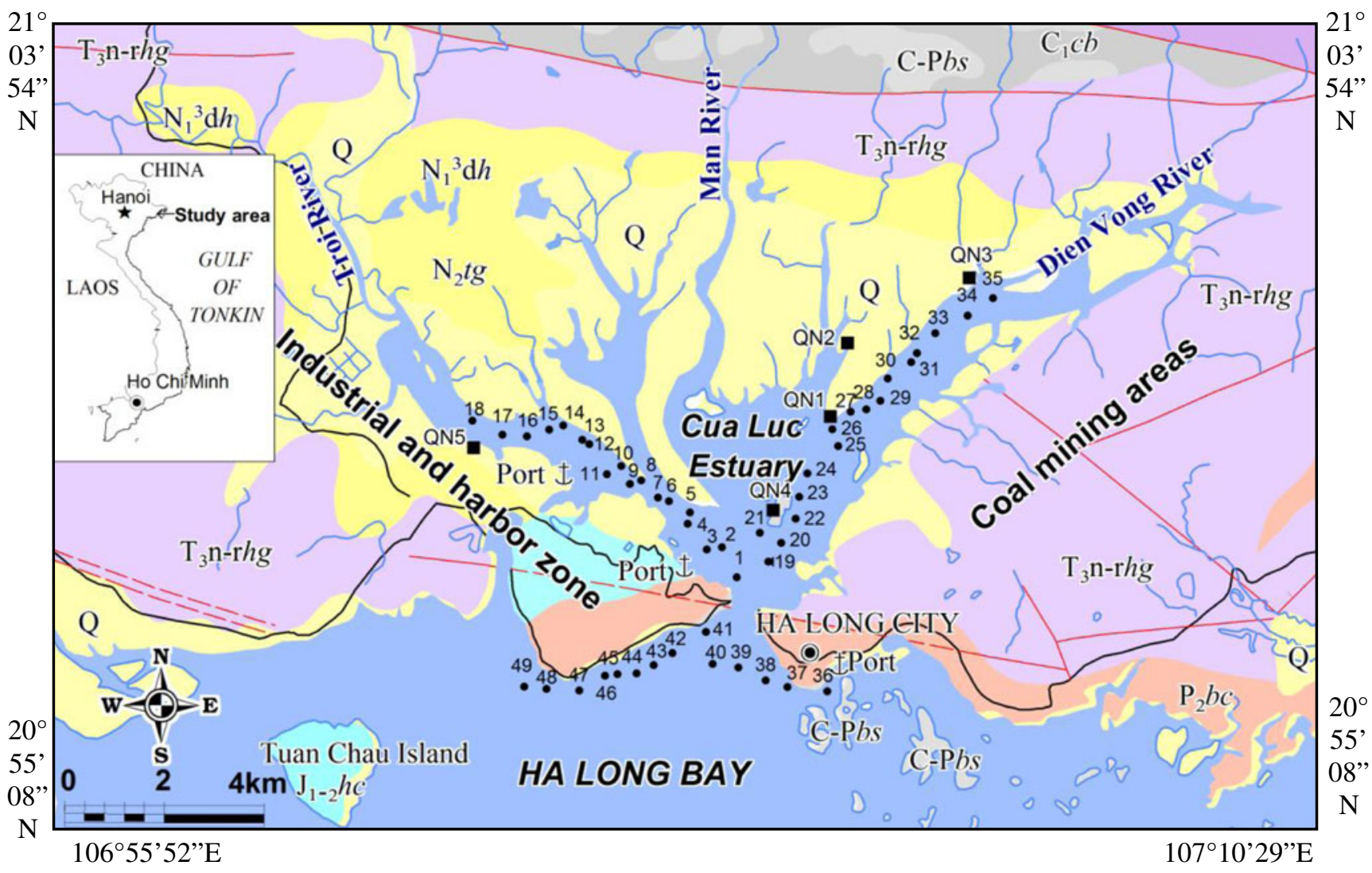

Fig. 1 Study area and sampling locations. Note: $\mathrm{C}_{1} c b$ Cat Ba Carboniferous and C-Pbs Bac Son Carboniferous and Permian Formations: dolomitized limestone and biogenic limestone; $\mathrm{P}_{2} b c$ Bai Chay Permian Formation: cherty and coaly shales, siltstone, and limestone lenses; $\mathrm{T}_{3} \mathrm{n}$-rhg Hon Gai Triassic Formation: sandstone, siltstone interbedded by shale and thick coal layers; $\mathrm{J}_{1-2} h c$ Ha Coi Jurassic
Formation: conglomerate, gridstone, sandstone, siltstone, and thin layers of coaly shale; $\mathrm{N}_{1} d h$ Dong Ho Neogene and $\mathrm{N}_{2} t g$ Tieu Giao Neogene Formations: conglomerate, sandstone, gridstone, and claystone; Q Quaternary unconsolidated sediments: sand, silt, clay, and little of pebble, cobble and shell of organisms; filled circles surficial bed sediment sample; filled squares core-sediment sample 
than $300 \mathrm{~km}^{2}$. The discharge of the rivers, depending seasonally on the rainfall in upstream areas, ranges from several cubic meters per second during the dry period from November to April, up to $1,500 \mathrm{~m}^{3} / \mathrm{s}$ at maximum during the floodwater season from May to October. In addition, the Cua Luc Estuary is also strongly influenced by diurnal tide with amplitude between 1 and $4 \mathrm{~m}$. The flood and ebb tides create large tidal channels in the estuary. Generally, around $20-30 \%$ of the water volume of the estuary (estimated to amount to 34 million cubic meters) is frequently exchanged with Ha Long Bay by tide currents.

The geological substrate in the study area is mainly dominated by sandstone and siltstone interbedded by shale and thick coal layers that belong to the Hon Gai Triassic Formation in the central part. Moreover, conglomerate, gritstone, sandstone, siltstone, claystone, schist, and shale from the Bai Chay Permian, Ha Coi Jurassic, Dong Ho, and Tieu Giao Neogene Formations are also scattered in the area (Cong Luong 1980). Limestone from the Cat $\mathrm{Ba}$ Carboniferous and $\mathrm{Bac}$ Son Carboniferous and Permian Formations occupies small areas in the northern part and in $\mathrm{Ha}$ Long Bay. Quaternary unconsolidated sediments are distributed in beaches and alluvial grounds around the estuary.

Before 1954, there was no industry in the study area except some small-scale coal-mining activities with a production of some 10,000 tons per year. More than $90 \%$ of the population in Quang Ninh province lived on agriculture and offshore fishing. The industry as well as the large-scale coalmining activities just started after 1954 when Northern Vietnam was liberated from the French rule and strongly developed since 1980 up to now. At present, there are an industrial and harbor zone in the southwest of the estuary while large-scale open-cast coal mining and residential activities occur in the east and northeast of the estuary and tourism in Ha Long Bay. The output of coal production is currently around some 10,000,000 tons per year.

Previous studies assessing the pollution by trace metals are scarce in the area. Thuc Anh (2006) tried to assess the anthropogenic contributions, based on the comparison of total metal concentrations with the Interim Canadian Sediment Quality Guidelines (SQG) [threshold effect level (TEL) $-\mathrm{As}=7.2 \mu \mathrm{g} / \mathrm{g}, \mathrm{Cd}=0.7 \mu \mathrm{g} / \mathrm{g}, \mathrm{Cr}=52.3 \mu \mathrm{g} / \mathrm{g}, \mathrm{Cu}=$ $18.7 \mu \mathrm{g} / \mathrm{g}, \mathrm{Ni}=15.9 \mu \mathrm{g} / \mathrm{g}, \mathrm{Pb}=30.2 \mu \mathrm{g} / \mathrm{g}$, and $\mathrm{Zn}=124 \mu \mathrm{g} /$ g]. She found that $\mathrm{Pb}, \mathrm{Cu}$, and $\mathrm{Cr}$ exceed the Canadian Sediment Quality Guidelines by one to two times and As is two to six times above the guideline, and hence she concluded that the sediments were polluted by these elements. However, the assessment based on the SQGs is rather arbitrary and normally leads to over- or underestimation of the risk of trace metal pollution in a specific area (SzarekGwiazda et al. 2011). Moreover, in a previous study (Ho et al. 2010) in Cua Ong area which is also another estuary of
Ha Long Bay and is $20 \mathrm{~km}$ away from the Cua Luc Estuary, the degree of contamination was assessed based on the comparison of trace metal concentrations in surficial sediments with reference values from the continental crusts (i.e., upper continental crust and average continental crust) and average sedimentary rocks. The authors concluded that the sediments are contaminated with As whereas $\mathrm{Co}, \mathrm{Cr}, \mathrm{Cu}$, $\mathrm{Mn}, \mathrm{Ni}, \mathrm{Pb}$, and $\mathrm{Zn}$ seem to reflect their background concentrations in sediments of Ha Long Bay. Since the local background levels of trace metals in the area had not been determined, these conclusions may be not completely correct. Therefore, in the present study, pre-industrial sediments (or deep core sediments) are also collected and the local background levels of trace metals are determined and coupled with ${ }^{137} \mathrm{Cs}$ dating values to assess the contribution of natural vs. anthropogenic sources of trace metals in the Cua Luc Estuary and Ha Long Bay.

\section{Sampling and Sample Pretreatment}

Two sampling campaigns were carried out in January 2008 and January 2009. Forty-nine surficial-bed sediment samples (uppermost $3 \mathrm{~cm}$ ) were collected by a stainless steel trihedral pyramid-shaped 5-1 grab at approximately 500-m intervals between neighboring samples ( 35 samples in Cua Luc Estuary and 14 samples in Ha Long Bay) (Fig. 1). In addition, five sediment cores (including QN1, QN2, QN3, QN4, and QN5 with a length of $210,160,60,55$, and $70 \mathrm{~cm}$, respectively) were also collected at intertidal grounds and alluvial spits around the Cua Luc Estuary by inserting PVC tubes $(\Phi=110 \mathrm{~mm})$ into the sediments.

During sampling, precaution was taken to minimize any disturbance in the grain size distribution of the original sediment. The grab was firmly closed by a cover when pulled up to the boat to avoid any leakage of fine material withdrawn by water. Moreover, to minimize metal contamination from the grab, the outer part of the sediment sample was removed and only the inner part was collected. For the PVC sampler, the exact composition of the PVC tube was not known, so after removing the PVC tube, the $1 \mathrm{~cm}$ outer part of the sediment core was whittled out by a stainless steel knife.

After collection, the sediment cores were sectioned in slices with a thickness of 2 to $10 \mathrm{~cm}$. Particularly, the cores QN1, QN2, QN3, QN4, and QN5 were divided into 21, 16, 20, 19, and 25 subsamples, respectively. Finally, the surficial-bed sediment and core sediment samples were placed in tightly sealed plastic containers and transported to the Vietnam Institute of Geosciences and Mineral Resources. Here, the samples were dried at $40{ }^{\circ} \mathrm{C}$ for 5 days and then disaggregated in an agate mortar, homogenized, and sieved over a $1-\mathrm{mm}$ sieve. Almost all sediment constituents were smaller than $1 \mathrm{~mm}$ in size except for some quartz 
particles, shells, and remains of plants. Since these big-size materials nearly do not contain trace metals, the $<1-\mathrm{mm}$ sieved material can be considered sufficiently representative for the sediments in the study area, and this was used for further analyses (Adamo et al. 2005).

\section{Analyses and Quality Control}

All analyses were carried out at the Department of Earth and Environmental Sciences, Catholic University of Leuven (KU Leuven, Belgium).

\section{Total Element, Organic Matter, pH, Grain-Size, and Mineralogical Analyses}

All surficial-bed sediment and core-sediment samples were analyzed for total-elemental composition by the so-called four-acid digestion method. One gram of dry sediment was put in a Teflon beaker. After adding $20 \mathrm{ml} \mathrm{HNO}_{3 \text { conc, }}$, the beaker was gently shaken and put on a hot plate at $200{ }^{\circ} \mathrm{C}$ until almost dry. Next, $20 \mathrm{ml} \mathrm{HClO}_{4 \text { conc }}$ was added to the beaker (covered with a loose cap) and heated at $240{ }^{\circ} \mathrm{C}$ until almost dry. Next, $20 \mathrm{ml} \mathrm{HF}$ conc was added to the beaker and heated at $240{ }^{\circ} \mathrm{C}$ until completely dry. Subsequently, the mixture was digested again in $5 \mathrm{ml} \mathrm{HClO}_{4 \text { conc }}$ at $240{ }^{\circ} \mathrm{C}$ until almost dry. Finally, the mixture was dissolved by adding $20 \mathrm{ml} 2.5 \mathrm{M} \mathrm{HCl}$ and put on a hot plate until the solid particles were entirely dissolved in the acid solution. The solution was filtered by a Whatman membrane filter and diluted to $50 \mathrm{ml}$ with Milli-Q water. Finally, the obtained solutions were measured by ICP-OES (Varian 720ES) for $\mathrm{Al}, \mathrm{K}, \mathrm{Ca}, \mathrm{Mg}, \mathrm{Fe}, \mathrm{As}, \mathrm{Co}, \mathrm{Cr}, \mathrm{Cu}, \mathrm{Mn}, \mathrm{Ni}, \mathrm{Pb}$, and $\mathrm{Zn}$. The samples were measured three times by ICP-OES to control the analytical precision in which the standard deviation was less than $5 \%$ for all elements. The efficiency of the digestion procedure and the analytical quality were controlled by the use of standard reference material BCSS-1 (marine sediment). The comparison between the measured concentrations with the certified data illustrates a good agreement for almost all the elements (Table 1).

The grain-size composition of sediments was determined by means of laser diffraction spectrophotometry (Malvern
Mastersizer S long bed; Malvern, Worcestershire, UK) after carbonates, iron hydr/oxides, and organic matter were removed by using $1.5 \mathrm{M} \mathrm{HCl}, 0.5 \mathrm{wt} . \%$ oxalic acid, and $8.8 \mathrm{M}$ $\mathrm{H}_{2} \mathrm{O}_{2}$, respectively.

Major and clay minerals in sediments were identified and quantified by the X-ray diffraction method (XRD). Quantitative XRD analysis was performed on bulk samples. All samples were hand-ground, mixed with an internal standard, and milled for 5 min using a McCrone micronizing mill (Srodon et al. 2001). The mineral powders were sideloaded into the XRD holders ensuring optimal random orientation of the crystallites. XRD analyses were performed with a Phillips PW1830 diffractometer from $5^{\circ}$ to $70^{\circ} 2 \theta$, step size $0.02^{\circ}$, and 2 -s counting time per step. Interpretation and quantification was performed using the full pattern fitting software QUANTA (CChevron ETC).

Moreover, organic matter content was quantified by the Walkley-Black manual titration method (Schumacher 2002). Sediment $\mathrm{pH}$ was measured in a suspension with a solid/liquid ratio of $1: 5$ of sediment in a $\mathrm{CaCl}_{2} \cdot 2 \mathrm{H}_{2} \mathrm{O} 0.01 \mathrm{M}$ solution after shaking for $2 \mathrm{~h}$ (ISO 10390 2005).

\section{${ }^{137}$ Cs Activity Analysis}

${ }^{137} \mathrm{Cs}$-isotope analysis was carried out for dating the sediment core QN1. The ${ }^{137} \mathrm{Cs}$ activity in 17 sediment samples of this core was determined by gamma spectrometry counting on $150 \mathrm{~g}$ of sample for up to $24 \mathrm{~h}$ using a high-purity germanium detector (HPGe) coupled to a multi-channel analyzer. The geochronology for sediment layers was based upon fallout of the fission product ${ }^{137} \mathrm{Cs}$ from the stratosphere where it was introduced by nuclear testing. The peak of the ${ }^{137} \mathrm{Cs}$ activity distribution is assumed to correspond to 1963 , the year of the atmospheric weapons test ban treaty (Ritchie and McHenry 1990).

\section{BCR Three-Step Sequential Extraction (Rauret et al. 1999)}

A BCR (Community Bureau of Reference) three-step sequential extraction procedure that differentiates between the exchangeable and carbonate-bound, reducible (Fe/Mn hydr/ oxides), oxidizable (sulfide and organic matter-bound), and

Table 1 Comparison between the measured concentrations with certified data of the standard reference material BCSS-1 (marine sediment) $(n=3)$

\begin{tabular}{|c|c|c|c|c|c|c|c|c|c|c|c|c|c|}
\hline & \multicolumn{5}{|c|}{ Major element (\%) } & \multicolumn{8}{|c|}{ Trace element $(\mu \mathrm{g} / \mathrm{g})$} \\
\hline & $\mathrm{Al}$ & $\mathrm{Ca}$ & $\mathrm{Fe}$ & K & $\mathrm{Mg}$ & As & Co & $\mathrm{Cr}$ & $\mathrm{Cu}$ & $\mathrm{Mn}$ & $\mathrm{Ni}$ & $\mathrm{Pb}$ & $\mathrm{Zn}$ \\
\hline Mean & 6.10 & 0.57 & 3.24 & 1.82 & 1.45 & 10.9 & 10.8 & 88.3 & 19.8 & 215.2 & 53.2 & 21.5 & 130.1 \\
\hline STDEV & 0.01 & 0.03 & 0.02 & 0.01 & 0.02 & 0.6 & 0.1 & 3.2 & 0.5 & 2.1 & 0.1 & 0.2 & 1.1 \\
\hline Certified & 6.26 & 0.54 & 3.29 & 1.80 & 1.46 & 11 & 11 & 123 & 19 & 229 & 55 & 23 & 119 \\
\hline Recovery (\%) & 97 & 106 & 99 & 101 & 99 & 99 & 95 & 72 & 107 & 94 & 96 & 94 & 109 \\
\hline
\end{tabular}


residual (in lattice of primary and secondary minerals) fractions is commonly applied to make a distinction between different geochemical forms of trace metals and to assess the potential mobility of trace metals in sediment (Tack and Verloo 1995).

Sediment core QN1 was also chosen for the BCR three-step extraction to evaluate the fractionation as well as the mobility of trace metals in the study area. This sequential extraction procedure included the three following steps:

- Step 1: $0.5 \mathrm{~g}$ dry sediment was extracted with $20 \mathrm{ml}$ of $0.11 \mathrm{M} \mathrm{CH}_{3} \mathrm{COOH}(\mathrm{pH}=2.70)$ in a $50 \mathrm{ml}$ centrifuge tube for $16 \mathrm{~h}$. This fraction is considered to correspond to the exchangeable and carbonate-bound metals (or acid-soluble fraction).

- Step 2: the residue from step 1 is subsequently extracted with $20 \mathrm{ml}$ of a freshly prepared $0.5 \mathrm{M} \mathrm{NH}_{2} \mathrm{OH} \cdot \mathrm{HCl}$ $(\mathrm{pH}=1.14)$ for $16 \mathrm{~h}$. This fraction is considered to correspond to the Fe and Mn hydr/oxides-bound metals (or reducible fraction).

- Step 3: the residue from step 2 is subsequently digested two times with $5 \mathrm{ml}$ of $8.8 \mathrm{M} \mathrm{H}_{2} \mathrm{O}_{2}$ at $85 \pm 2{ }^{\circ} \mathrm{C}$ and then extracted with $25 \mathrm{ml}$ of $1 \mathrm{M}$ $\mathrm{CH}_{3} \mathrm{COONH}_{4}(\mathrm{pH}=2.00)$ for $16 \mathrm{~h}$. This fraction is considered to correspond to the organic matter and sulfides-bound metals (or oxidizable fraction).

All three extraction steps were performed by shaking in a reciprocal shaker at a room temperature of $22 \pm 3{ }^{\circ} \mathrm{C}$. The residue after each step was washed by adding $10 \mathrm{ml}$ MilliQ water, shaking for $15 \mathrm{~min}$, and centrifuging at 3,000 rpm for $20 \mathrm{~min}$ before using for the next step. The obtained extracts were measured by ICP-OES for $\mathrm{Al}, \mathrm{K}, \mathrm{Ca}, \mathrm{Mg}, \mathrm{Fe}$, As, Co, $\mathrm{Cu}, \mathrm{Mn}, \mathrm{Ni}, \mathrm{Pb}$, and $\mathrm{Zn}$. The residual fraction (lattice-related elements of primary and secondary minerals) was obtained from the difference between the total-elemental analysis and the sum of steps 1, 2, and 3 for each element. The efficiency of the extraction procedure was controlled by the use of the standard reference material BCR 701. The comparison between the measured concentrations with the certified data illustrates a good agreement for most elements (Table 2).

\section{Instruments and Reagents}

All reagents were of ultra-pure quality (Chem-Lab NV Belgium). All the labware and the laboratory instruments used were thoroughly cleaned before utilization, and all materials used for treatment and storage of the samples were non-metallic (plastic, glass, or stainless steel).

\section{Data Processing}

Statistical analyses including the Pearson product-moment correlation, factor analysis, and multiple linear regression were performed for 49 surficial-sediment samples by the statistical software STATISTICA version 8.0. Since for those parametric statistical treatments an obligatory condition of input data was the "normality of variables", a normality testing was carried out based on histograms, probability plots, and the Shapiro-Wilks test. In nature, many major and trace elements usually have a close to logarithmic distribution (Batista et al. 2006). Therefore, for $\mathrm{Ca}, \mathrm{Mg}, \mathrm{Co}, \mathrm{Cu}, \mathrm{Pb}$, and $\mathrm{Zn}$, a logarithmic transformation was performed to obtain a population distribution as close as possible to normality. Thus, the final data set consists of a combination between raw data for the normally distributed variables $(\mathrm{Al}, \mathrm{K}, \mathrm{Fe}, \mathrm{OM}$, As, $\mathrm{Cr}, \mathrm{Mn}, \mathrm{Ni}, \mathrm{pH}$, and clay and fine fractions) and $\log _{10}$-transformed data for $\mathrm{Ca}, \mathrm{Mg}, \mathrm{Co}, \mathrm{Cu}, \mathrm{Pb}$, and $\mathrm{Zn}$ in an attempt to satisfy the normality condition.

\section{Results and Discussion}

\section{Sediment Characterization}

Statistical parameters for chemical, grain-size, and mineralogical characteristics of the sediments in the Cua Luc Estuary and Ha Long Bay are given in Table 3. The studied sediments are classified mainly as silty sand or sandy silt according to the Folk (1980) classification. If compared with the upper continental crust and the

Table 2 Comparison between measured concentrations with certified data of the reference material BCR 701 in the BCR three-step sequential extraction $(n=2)$

\begin{tabular}{|c|c|c|c|c|c|c|c|c|c|c|c|c|c|c|c|}
\hline & \multicolumn{3}{|l|}{$\mathrm{Cr}$} & \multicolumn{3}{|l|}{$\mathrm{Cu}$} & \multicolumn{3}{|l|}{$\mathrm{Ni}$} & \multicolumn{3}{|l|}{$\mathrm{Pb}$} & \multicolumn{3}{|l|}{$\mathrm{Zn}$} \\
\hline & St1 & St2 & St3 & St1 & St2 & St3 & St1 & St2 & St3 & St1 & St2 & St3 & St1 & St2 & St3 \\
\hline Measured ( $\mu \mathrm{g} / \mathrm{g})$ & 2.9 & 49.1 & 124.1 & 52.3 & 117.5 & 48.1 & 12.3 & 22.6 & 12.8 & 4.0 & 125.3 & 7.7 & 198.4 & 112.2 & 47.8 \\
\hline SD & 0.4 & 0.5 & 0.3 & 0.0 & 0.5 & 0.3 & 0.1 & 1.2 & 0.7 & 0.1 & 2.4 & 0.4 & 1.1 & 0.5 & 0.2 \\
\hline Certified $(\mu \mathrm{g} / \mathrm{g})$ & 2.26 & 45.7 & 143 & 49.3 & 124 & 55.2 & 15.4 & 26.6 & 15.3 & 3.18 & 126 & 9.3 & 205 & 114 & 45.7 \\
\hline Recovery (\%) & 128 & 107 & 87 & 106 & 95 & 87 & 80 & 85 & 83 & 126 & 99 & 83 & 97 & 98 & 105 \\
\hline
\end{tabular}


Table 3 Statistical parameters for geochemical characteristics of the sediments in the Cua Luc Estuary and Ha Long Bay

\begin{tabular}{|c|c|c|c|c|c|c|c|c|}
\hline & & Unit $^{\mathrm{a}}$ & Min & $\operatorname{Max}$ & Average & SD & Upper continental crust ${ }^{\mathrm{b}}$ & Average shale ${ }^{c}$ \\
\hline \multirow[t]{15}{*}{ Chemical composition $(n=150)$} & $\mathrm{Al}$ & $\%$ & 0.72 & 7.48 & 3.04 & 1.36 & 8.03 & 8.0 \\
\hline & $\mathrm{K}$ & $\%$ & 0.29 & 2.79 & 0.99 & 0.41 & 2.81 & 2.66 \\
\hline & $\mathrm{Ca}$ & $\%$ & 0.08 & 1.18 & 0.23 & 0.17 & 2.99 & 2.21 \\
\hline & $\mathrm{Mg}$ & $\%$ & 0.24 & 1.62 & 0.60 & 0.31 & 1.32 & 1.50 \\
\hline & $\mathrm{Fe}$ & $\%$ & 0.68 & 3.83 & 1.89 & 0.63 & 3.49 & 4.72 \\
\hline & As & $\mu \mathrm{g} / \mathrm{g}$ & 4 & 26 & 14 & 4 & 1.5 & 13 \\
\hline & Co & $\mu \mathrm{g} / \mathrm{g}$ & 2 & 16 & 7 & 3 & 17 & 19 \\
\hline & $\mathrm{Cr}$ & $\mu \mathrm{g} / \mathrm{g}$ & 11 & 103 & 44 & 20 & 85 & 90 \\
\hline & $\mathrm{Cu}$ & $\mu \mathrm{g} / \mathrm{g}$ & 5 & 53 & 14 & 6 & 25 & 45 \\
\hline & Mn & $\mu \mathrm{g} / \mathrm{g}$ & 22 & 427 & 110 & 79 & 500 & 850 \\
\hline & $\mathrm{Ni}$ & $\mu \mathrm{g} / \mathrm{g}$ & 10 & 38 & 19 & 5 & 44 & 68 \\
\hline & $\mathrm{Pb}$ & $\mu \mathrm{g} / \mathrm{g}$ & 8 & 77 & 18 & 7 & 17 & 20 \\
\hline & $\mathrm{Zn}$ & $\mu \mathrm{g} / \mathrm{g}$ & 25 & 157 & 65 & 22 & 71 & 95 \\
\hline & $\mathrm{OM}$ & $\%$ & 0.25 & 9.79 & 2.94 & 1.51 & & \\
\hline & $\mathrm{pH}$ & & 3.06 & 8.14 & 5.56 & 1.42 & & \\
\hline \multirow[t]{3}{*}{ Grain size $(n=60)$} & Clay $(<2 \mu \mathrm{m})$ & $\%$ & 4.4 & 26.8 & 11.5 & 3.9 & & \\
\hline & Silt $(2-63 \mu \mathrm{m})$ & $\%$ & 21.8 & 87.9 & 63.5 & 15.4 & & \\
\hline & Sand $(>63 \mu \mathrm{m})$ & $\%$ & 0.3 & 73.9 & 25.0 & 18.1 & & \\
\hline
\end{tabular}

\footnotetext{
${ }^{a}$ The unit is on basis of dry matter

${ }^{\mathrm{b}}$ According to Taylor and McLennan $(1985,1995)$

${ }^{\mathrm{c}}$ According to Turekian and Wedepohl (1961)
}

average shale, the contents of major elements ( $\mathrm{Al}, \mathrm{K}$, $\mathrm{Ca}, \mathrm{Mg}$, and $\mathrm{Fe}$ ) are low. The concentrations of $\mathrm{As}, \mathrm{Pb}$, and $\mathrm{Zn}$ are rather equivalent while those of $\mathrm{Co}, \mathrm{Cr}, \mathrm{Cu}$, $\mathrm{Mn}$, and $\mathrm{Ni}$ are lower than their reference values. Organic matter content widely varies from $0.25 \%$ to $9.79 \%$. The $\mathrm{pH}$ values range from 3.06 to 8.14 and indicate an acidic to slightly alkaline medium. The low $\mathrm{pH}$ values (around 3) are found in sediment samples with high contents of organic matter and sulfides in mangrove areas, so they are possibly explained by the combination of a low acid neutralizing capacity of the sediments and the (partial) oxidation of sulfides in sediments (Cappuyns et al. 2006).

Spatial Distribution of Trace Metals and Controlling Factors

The spatial distribution patterns of concentrations of major elements ( $\mathrm{Al}, \mathrm{K}, \mathrm{Ca}, \mathrm{Mg}$, and $\mathrm{Fe}$ ), organic matter, and clay and fine fractions are shown in Fig. 2, while trace metal concentrations are presented in Fig. 3. Class subdivision is based on the percentile values $(25 \%$, $50 \%, 75 \%$ ), thus emphasizing the occurrence of higher and lower concentration values (Dinelli et al. 2005).

The fine $(\Phi<63 \mu \mathrm{m})$ fraction, ranging from $30.9 \%$ to $99.5 \%$, generally shows higher values in Ha Long Bay if compared with the Cua Luc Estuary. Similarly, major elements such as $\mathrm{Al}, \mathrm{Fe}, \mathrm{Ca}$, and $\mathrm{Mg}$, varying between $1.1 \%$ and $7.2 \%, 0.8-3.8 \%, 0.08-0.55 \%$, and $0.2-1.9 \%$, respectively, show higher concentrations in Ha Long Bay. In contrast, clay $(\Phi<2 \mu \mathrm{m}), \mathrm{K}$, and organic matter, varying between $5.5 \%$ and $26.9 \%, 0.5-2.8 \%$, and $0.7-4.4 \%$, respectively, show high concentrations both in Ha Long Bay and in mangrove areas of the Cua Luc Estuary. Trace metals, including Co $(4-13 \mu \mathrm{g} / \mathrm{g}), \mathrm{Cr}(18-88 \mu \mathrm{g} / \mathrm{g}), \mathrm{Cu}(5-$ $53 \mu \mathrm{g} / \mathrm{g}), \mathrm{Mn}(21-427 \mu \mathrm{g} / \mathrm{g}), \mathrm{Ni}(13-33 \mu \mathrm{g} / \mathrm{g}), \mathrm{Pb}(8-77 \mu \mathrm{g} / \mathrm{g})$, Zn (39-157 $\mu \mathrm{g} / \mathrm{g})$, and As (6-21 $\mu \mathrm{g} / \mathrm{g})$, generally display higher concentrations in Ha Long Bay when compared with the Cua Luc Estuary.

In order to determine the sediment properties [i.e., clay and fine fractions, $\mathrm{pH}$, organic matter, and major elements ( $\mathrm{Al}, \mathrm{K}, \mathrm{Fe}, \mathrm{Ca}$, and $\mathrm{Mg}$ )] that control the spatial distribution of trace metals, a Pearson productmoment correlation matrix was used (Table 4). Aluminum has a strong correlation with the fine fraction $(\Phi<63 \mu \mathrm{m})(r=0.82)$, and both are significantly correlated with other variables $(r \geq 0.40)$. Since Al is considered representative for aluminosilicate minerals, which is the main component of the fine fraction, all other variables including the clay fraction $(\Phi<2 \mu \mathrm{m}), \mathrm{K}, \mathrm{Fe}$, $\mathrm{Ca}, \mathrm{Mg}, \mathrm{As}, \mathrm{Co}, \mathrm{Cr}, \mathrm{Cu}, \mathrm{Mn}, \mathrm{Ni}, \mathrm{Pb}$, and $\mathrm{Zn}$ content are more or less related to aluminosilicate components (Rubio et al. 2000). Generally, all trace metals significantly correlate with each other $(r>0.3)$, and this may reflect their common origin. Al normally has stronger 

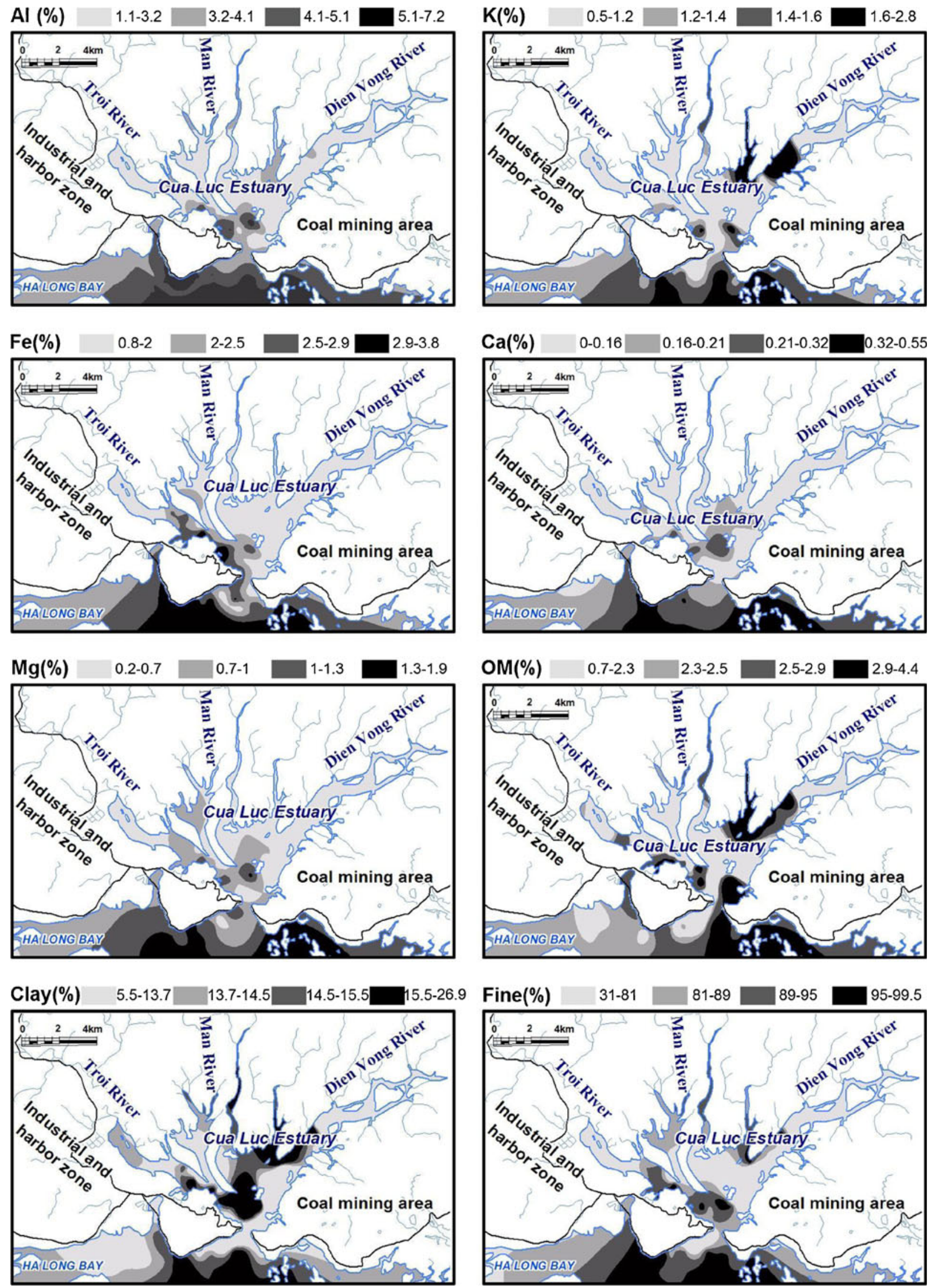

Fig. 2 Spatial distribution of the concentrations of $\mathrm{Al}, \mathrm{K}, \mathrm{Fe}, \mathrm{Ca}, \mathrm{Mg}$, organic matter, and clay and fine fractions in sediments 

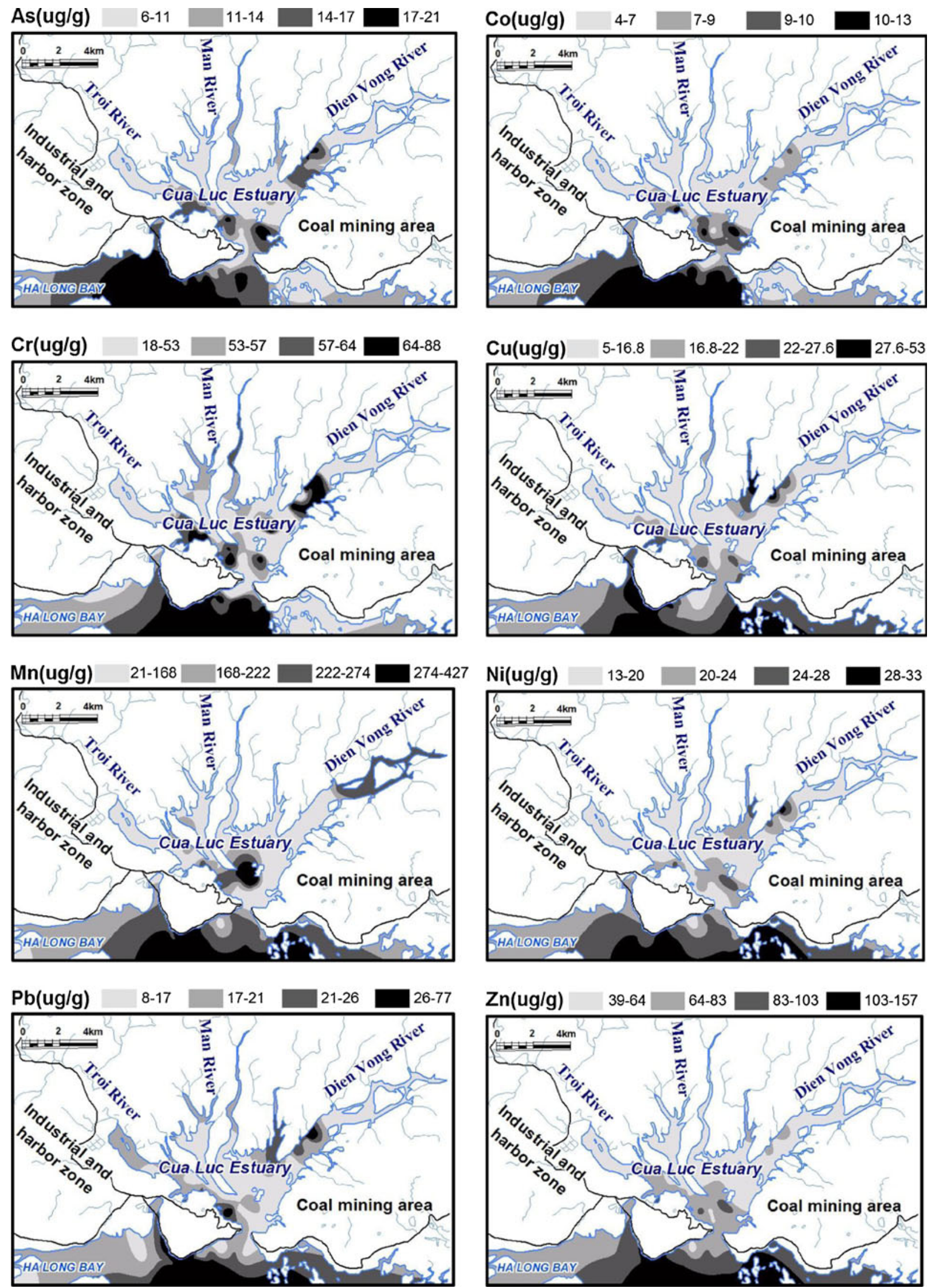

Fig. 3 Spatial distribution of the concentrations of trace metals in sediments 
Table 4 Pearson product-moment correlation matrix between geochemical variables for the surficial bed sediments $(n=49)$

\begin{tabular}{|c|c|c|c|c|c|c|c|c|c|c|c|c|c|c|c|c|}
\hline & $\mathrm{Al}$ & $\mathrm{K}$ & $\mathrm{Ca}$ & $\mathrm{Mg}$ & $\mathrm{Fe}$ & As & $\mathrm{Co}$ & $\mathrm{Cr}$ & $\mathrm{Cu}$ & $\mathrm{Mn}$ & $\mathrm{Ni}$ & $\mathrm{Pb}$ & $\mathrm{Zn}$ & OM & $\mathrm{pH}$ & Clay \\
\hline $\mathrm{K}$ & 0.66 & & & & & & & & & & & & & & & \\
\hline $\mathrm{Ca}$ & 0.74 & 0.39 & & & & & & & & & & & & & & \\
\hline $\mathrm{Mg}$ & 0.77 & 0.30 & 0.78 & & & & & & & & & & & & & \\
\hline $\mathrm{Fe}$ & 0.90 & 0.43 & 0.70 & 0.88 & & & & & & & & & & & & \\
\hline As & 0.76 & 0.81 & 0.59 & 0.58 & 0.64 & & & & & & & & & & & \\
\hline Co & 0.80 & 0.63 & 0.67 & 0.75 & 0.80 & 0.82 & & & & & & & & & & \\
\hline $\mathrm{Cr}$ & 0.83 & 0.91 & 0.53 & 0.58 & 0.71 & 0.86 & 0.76 & & & & & & & & & \\
\hline $\mathrm{Cu}$ & 0.79 & 0.80 & 0.58 & 0.57 & 0.69 & 0.88 & 0.75 & 0.85 & & & & & & & & \\
\hline $\mathrm{Mn}$ & 0.69 & 0.16 & 0.69 & 0.82 & 0.78 & 0.44 & 0.71 & 0.42 & 0.39 & & & & & & & \\
\hline $\mathrm{Ni}$ & 0.82 & 0.83 & 0.71 & 0.66 & 0.69 & 0.88 & 0.81 & 0.90 & 0.81 & 0.51 & & & & & & \\
\hline $\mathrm{Pb}$ & 0.72 & 0.74 & 0.51 & 0.45 & 0.60 & 0.68 & 0.59 & 0.75 & 0.71 & 0.26 & 0.74 & & & & & \\
\hline $\mathrm{Zn}$ & 0.89 & 0.61 & 0.78 & 0.82 & 0.87 & 0.81 & 0.87 & 0.77 & 0.80 & 0.69 & 0.85 & 0.78 & & & & \\
\hline $\mathrm{OM}$ & 0.40 & 0.69 & 0.16 & 0.12 & 0.18 & 0.62 & 0.37 & 0.55 & 0.57 & -0.07 & 0.50 & 0.44 & 0.36 & & & \\
\hline $\mathrm{pH}$ & 0.69 & 0.23 & 0.81 & 0.86 & 0.80 & 0.49 & 0.71 & 0.63 & 0.45 & 0.77 & 0.75 & 0.28 & 0.69 & -0.38 & & \\
\hline Clay & 0.62 & 0.74 & 0.21 & 0.26 & 0.44 & 0.64 & 0.44 & 0.72 & 0.67 & 0.15 & 0.54 & 0.58 & 0.49 & 0.66 & -0.08 & \\
\hline Fines & 0.82 & 0.72 & 0.43 & 0.55 & 0.73 & 0.72 & 0.65 & 0.84 & 0.79 & 0.42 & 0.68 & 0.63 & 0.71 & 0.55 & 0.52 & 0.88 \\
\hline
\end{tabular}

Bold correlation coefficient is significant with $p$ value $<0.05$

correlations with trace metals if compared to other major elements $(\mathrm{Fe}, \mathrm{Ca}, \mathrm{Mg}$, and $\mathrm{OM})$, which possibly indicates that aluminosilicate minerals are the main binding phases for trace metals. Moreover, the significant correlations of trace metals with $\mathrm{Fe}, \mathrm{Ca}$, and $\mathrm{Mg}$ $(r \geq 0.45)$ also indicate a possible relation to $\mathrm{Fe}$ compounds (e.g., Fe hydr/oxides, sulfides, etc.) and carbonates [e.g., calcite and dolomite $(<1 \%)$ ] in sediments. Organic matter has a significant correlation with As, Co, $\mathrm{Cr}, \mathrm{Cu}, \mathrm{Ni}, \mathrm{Pb}$, and $\mathrm{Zn}(r \geq 0.36)$. The $\mathrm{pH}$ is significantly correlated with total concentrations of $\mathrm{Co}, \mathrm{Cr}, \mathrm{Mn}$, $\mathrm{Ni}$, and $\mathrm{Zn}(r>0.63)$.

A factor analysis was also performed to detect the structure in the relationships between variables, and thus allowing classifying variables (Batista et al. 2006). Two factors (Eigenvalue $>1$ ), which explain $79 \%$ of the total geochemical variance in the study area, are defined (Table 5).

- Factor 1 (accounting for $63.4 \%$ of the total variance) is characterized by high loadings of $\mathrm{Al}, \mathrm{K}$, $\mathrm{Fe}, \mathrm{As}, \mathrm{Co}, \mathrm{Cr}, \mathrm{Cu}, \mathrm{Ni}, \mathrm{Pb}, \mathrm{Zn}, \mathrm{OM}$, clay and fine fraction, and moderate loadings of $\mathrm{Ca}$ and $\mathrm{Mg}$. This group is related to aluminosilicate components in the studied sediment. Organic matter and iron hydr/oxides that may form an armouring layer on the surface of clay particles (Wang and Chen 2000; Chen et al. 2007) also likely contribute to this group.

- Factor 2 (accounting for $15.4 \%$ of the total variance) is characterized by high loadings of $\mathrm{Ca}, \mathrm{Mg}, \mathrm{Fe}, \mathrm{Mn}$, and
$\mathrm{pH}$ and moderate loadings of $\mathrm{Al}, \mathrm{Co}$, and $\mathrm{Zn}$, and negative moderate loading of OM. This group may be controlled by carbonates and $\mathrm{Fe} / \mathrm{Mn}$ hydr/oxides and influenced by $\mathrm{pH}$.

Table 5 Factor loadings (Quartimax normalized) of the variables for the surficial bed sediments

\begin{tabular}{lcc}
\hline & Factor 1 & Factor 2 \\
\hline $\mathrm{Al}$ & $\mathbf{0 . 8 5}$ & 0.42 \\
$\mathrm{~K}$ & $\mathbf{0 . 9 0}$ & - \\
$\mathrm{Ca}$ & 0.55 & $\mathbf{0 . 6 5}$ \\
$\mathrm{Mg}$ & 0.55 & $\mathbf{0 . 7 4}$ \\
$\mathrm{Fe}$ & $\mathbf{0 . 6 9}$ & $\mathbf{0 . 6 1}$ \\
$\mathrm{As}$ & $\mathbf{0 . 9 1}$ & - \\
$\mathrm{Co}$ & $\mathbf{0 . 7 7}$ & 0.48 \\
$\mathrm{Cr}$ & $\mathbf{0 . 9 3}$ & - \\
$\mathrm{Cu}$ & $\mathbf{0 . 9 1}$ & - \\
$\mathrm{Mn}$ & - & $\mathbf{0 . 8 4}$ \\
$\mathrm{Ni}$ & $\mathbf{0 . 8 8}$ & - \\
$\mathrm{Pb}$ & $\mathbf{0 . 8 2}$ & - \\
$\mathrm{Zn}$ & $\mathbf{0 . 8 3}$ & 0.48 \\
$\mathrm{OM}$ & $\mathbf{0 . 7 1}$ & -0.46 \\
$\mathrm{pH}$ & - & $\mathbf{0 . 6 5}$ \\
Clay & $\mathbf{0 . 8 2}$ & - \\
Fines & $\mathbf{0 . 8 8}$ & - \\
Eigenvalue & 11.41 & 2.77 \\
\% Total variance & 63.36 & 15.40 \\
\hline $\mathrm{Bol}$ & & \\
\hline & &
\end{tabular}

Bold: high loading $(>0.6)$; regular: moderate loading (between 0.4 and $0.6)$. Low loading $(<0.4)$ is not shown 
In summary, trace metals ( $\mathrm{As}, \mathrm{Co}, \mathrm{Cr}, \mathrm{Cu}, \mathrm{Mn}, \mathrm{Ni}, \mathrm{Pb}$, and $\mathrm{Zn}$ ) generally display high concentrations in Ha Long Bay if compared with the Cua Luc Estuary. However, significant correlations of trace metals with the fine $(\Phi<$ $63 \mu \mathrm{m})$ and clay $(\Phi<2 \mu \mathrm{m})$ fractions as well as other sediment properties (i.e., $\mathrm{Al}, \mathrm{K}, \mathrm{Fe}, \mathrm{Ca}, \mathrm{Mg}$, and $\mathrm{OM}$ ) indicate that their high concentrations are due to high percentages of the fine and clay fractions, and hence high contents of aluminosilicate minerals, Fe/Mn hydr/oxides, carbonates, and organic matter. Since Al has a high loading in the first group and a moderate loading in the second group, it is considered to be a main geochemical characteristic which controls the distribution of trace metals in the studied sediments.

Assessment on Local Background Levels and Origin of Trace Metals in Sediments

\section{Sediment Characteristics with Depth}

Five sediment cores (QN1, QN2, QN3, QN4, and QN5) have been collected for the study. In all the cores, no evidences of organism activity (e.g., cavities, burrowing and ingestion tracks, etc.) were observed and the depositional structure of sediment layers was rather intact. This suggests that all the cores are not significantly affected by organism and human activities and are qualified appropriate for environmental studies. All five sediment cores were analyzed for total element composition and three cores were analyzed for grain-size composition (Table 6). Generally, the percentages of clay $(\Phi<2 \mu \mathrm{m})$ and fine $(\Phi<63 \mu \mathrm{m})$ fractions in all the cores highly vary with depth, indicating a change in hydrodynamic condition of the estuary with time. Consequently, this leads to a strong variation in concentrations of major and trace elements with depth in all five cores. In the framework of this paper, only the longest sediment core QN1 (with a total length of $210 \mathrm{~cm}$ ), which nearly locates in the center of the study area and has been used for all total element, grain-size, mineralogy, and ${ }^{137} \mathrm{Cs}$ dating analyses, is described (Fig. 4).

In the sediment core QN1, the sand $(\Phi=63-2,000 \mu \mathrm{m})$ fraction decreases while the silt $(\Phi=2-63 \mu \mathrm{m})$ and clay $(\Phi$ $<2 \mu \mathrm{m}$ ) fractions increase from top to bottom, which indicates a change from silty sand to sandy silt with depth according to the Folk (1980) classification. Mineral contents vary in the following order of abundance: quartz (47-83\%) $>$ Al-clays (illite and smectite) (13-38\%) > Fe-chlorite (2$4 \%$ ) $>$ kaolinite $(2-8 \%)>\mathrm{K}$-feldspar $(0.8-1 \%)>$ plagioclase $(0-0.7 \%)$ and pyrite $(0-2 \%)$. Quartz decreases while Alclays (illite and smectite), Fe-chlorite, kaolinite, and pyrite increase with depth. Chemically, except for $\mathrm{Ca}$ and organic matter that do not display any clear trend, other major elements ( $\mathrm{Al}, \mathrm{Fe}, \mathrm{K}$, and $\mathrm{Mg}$ ) increase with depth. The absolute concentrations of trace metals $(\mathrm{Co}, \mathrm{Cr}, \mathrm{Cu}, \mathrm{Mn}$, $\mathrm{Ni}, \mathrm{Pb}, \mathrm{Zn}$, and $\mathrm{As}$ ) increase with depth as a result of the distribution of grain-size and mineralogical compositions. However, after normalizing to aluminum to eliminate the granulometric and mineralogical effects, trace metals slightly decrease or are nearly unchanged with depth.

\section{${ }^{137}$ Cs-isotope Dating and Sedimentation Rate}

The distribution of ${ }^{137} \mathrm{Cs}$ activity along the sediment core QN1 is shown in Fig. 5. The peak of ${ }^{137} \mathrm{Cs}$ activity is located at $20-30 \mathrm{~cm}$ depth. Generally, the calculation of the sedimentation rate is based on the assumption that this peak is corresponding to the year 1963 and sedimentation is constant over time (Karbassi and Amirnezhad 2004). In the interval from 0 to $40 \mathrm{~cm}$ of the studied sediment core (QN1), the grain-size composition varies in the following range- sand: $32-50 \%$, silt: $43-58 \%$, and clay: $6-9 \%$, and the mineralogical composition varies in the following range-quartz: 78$83 \%$, Al-clays (illite and smectite): $13-14 \%$, Fechlorite: 2-3\%, kaolinite: $2-3 \%$, and K-feldspar, plagioclase, and pyrite (1-2\%), which shows little variation within this interval. This means that the hydrodynamic condition did not change much with time and suggests that the assumption of constant sedimentation rate can be accepted. Therefore, the sedimentation rate in the study area is estimated to be in the range of $0.43-0.65 \mathrm{~cm} /$ year.

\section{Background Equations of Trace Metals with Normalizer}

As reported by some authors (Schropp and Windom 1988; Loring and Rantala 1992; Swennen and Van der Sluys 1998), subsurface core sediments which were deposited during the pre-industrial period are preferentially suitable for assessing local background levels of trace metals because they are texturally and mineralogically equivalent to surficial sediments. As mentioned above, the period before 1954 is considered as pre-industrial because there was no industry except for small-scale sparse coal-mining activities in the study area. Since the sedimentation rate may be different between locations because of the difference in hydrodynamic condition, the marginal value of the estimated sedimentation rate (i.e., $0.65 \mathrm{~cm} /$ year) is considered for the year 1954 to minimize the error. The year 1954 is corresponding to a depth of $36 \mathrm{~cm}$. Consequently, 57 sediment samples in five cores which are below $36 \mathrm{~cm}$ depth are used for establishing local background levels.

Since the variability in the grain size and mineralogical composition needs to be taken into account in assessing the contamination of sediments, the local background levels in 


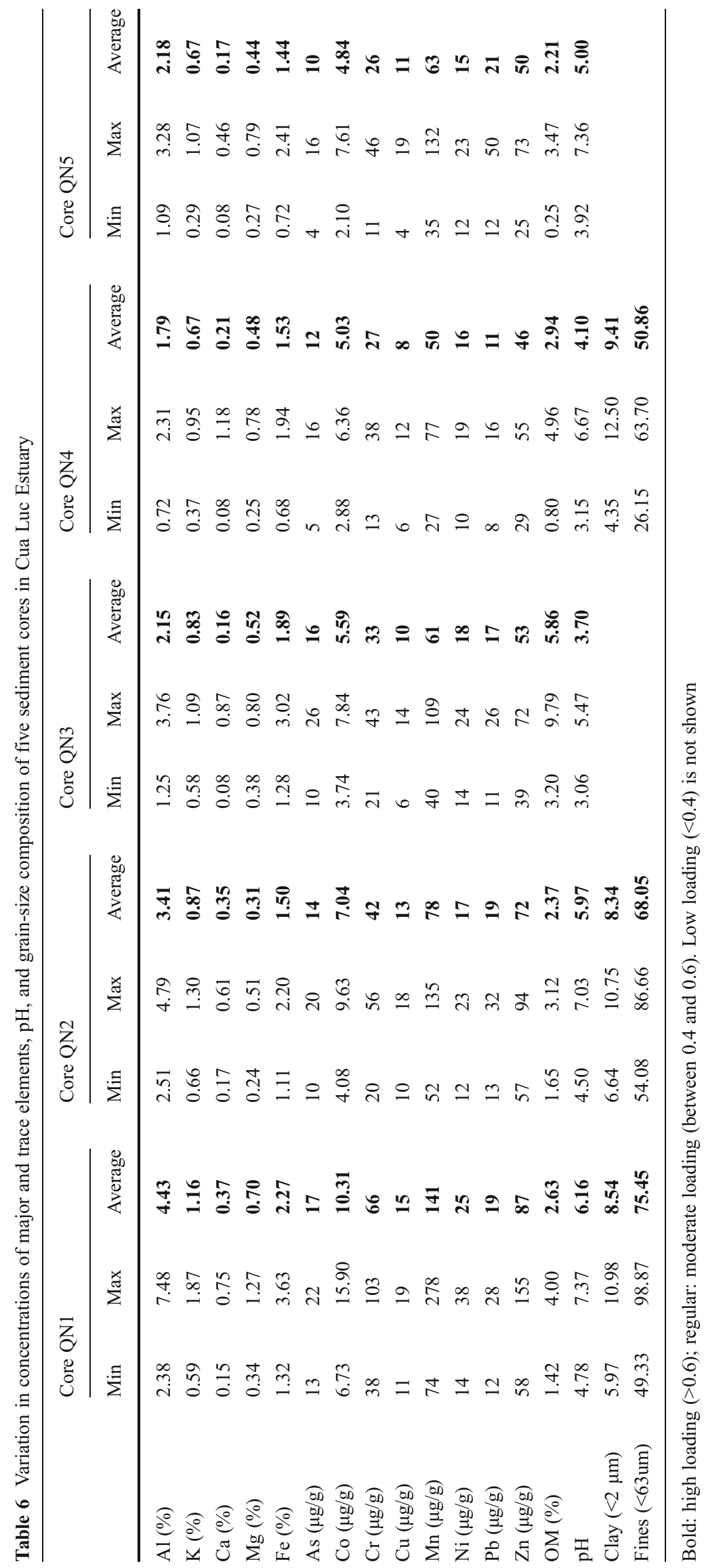



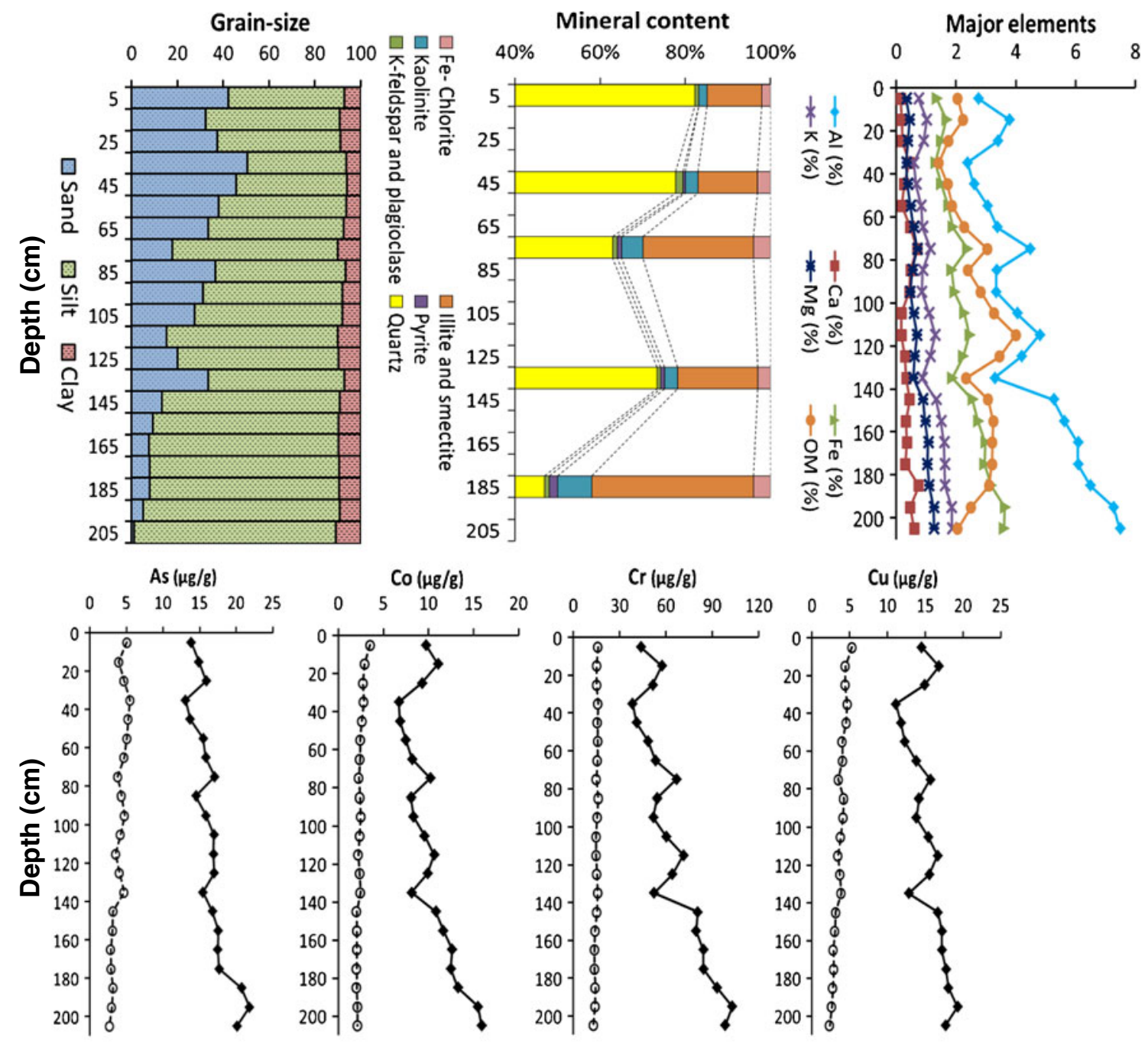

Co $(\mu \mathrm{g} / \mathrm{g})$

$\mathrm{Cr}$ ( $\mu \mathrm{g} / \mathrm{g})$

$\mathrm{Cu}(\mu \mathrm{g} / \mathrm{g})$

$\begin{array}{llllllllllllll}10 & 15 & 20 & 0 & 30 & 60 & 90 & 120 & 0 & 5 & 10 & 15 & 20 & 25\end{array}$
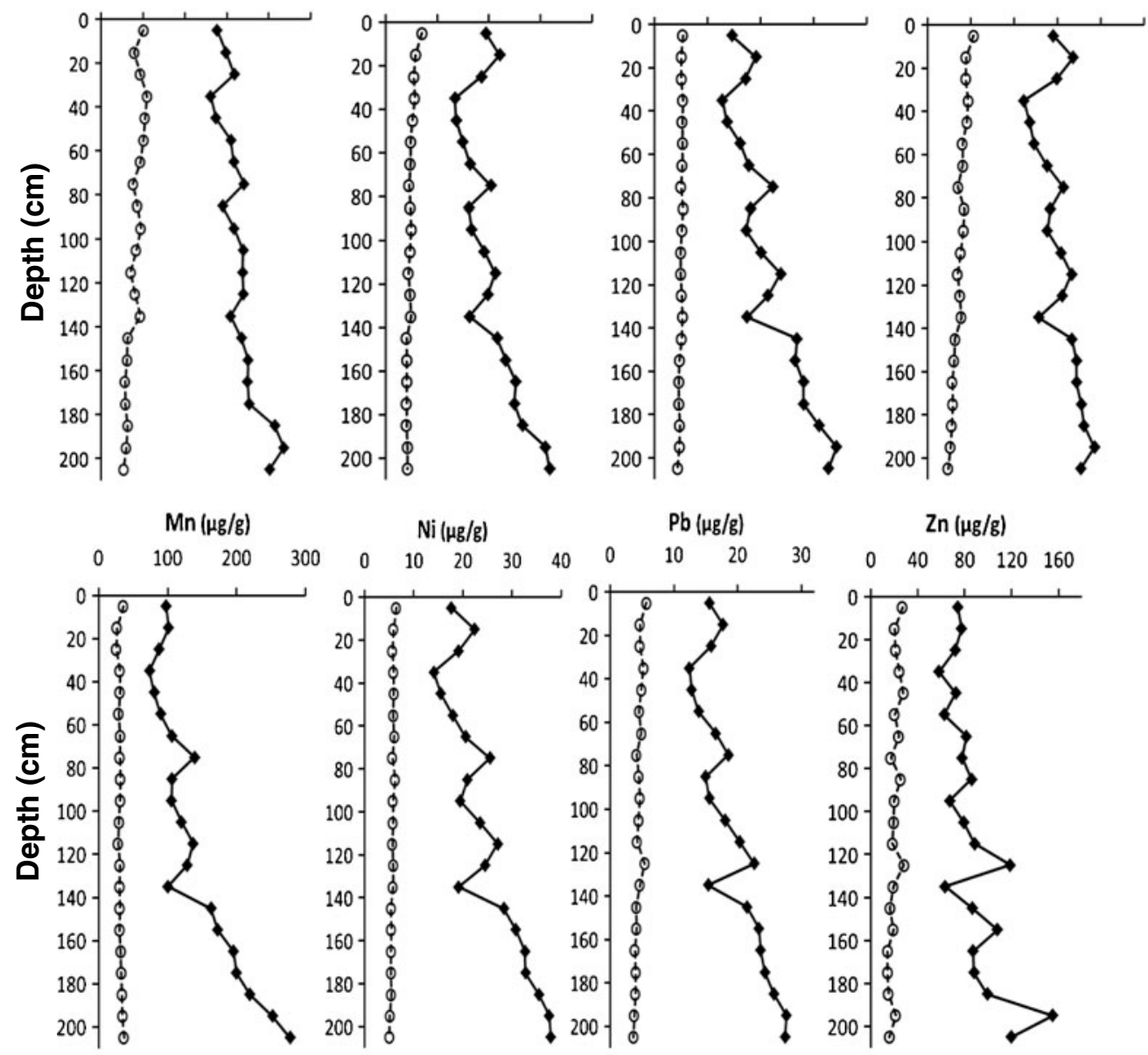

Fig. 4 Vertical distribution of grain-size and mineralogical compositions, major and trace elements in the sediment core QN1. Solid symbol and solid line indicate the absolute values, and open symbol and dashed line indicate Al-normalized concentrations of trace metals

terms of the relationships of trace metals with a normalizer, rather than their absolute values, should be established (Schropp and Windom 1988; Loring and Rantala 1992).
As mentioned in "Spatial Distribution of Trace Metals and Controlling Factors" section, Al has significant correlations with all other variables [i.e., $\mathrm{K}, \mathrm{Fe}, \mathrm{Ca}, \mathrm{Mg}, \mathrm{As}, \mathrm{Co}, \mathrm{Cr}, \mathrm{Cu}$, 


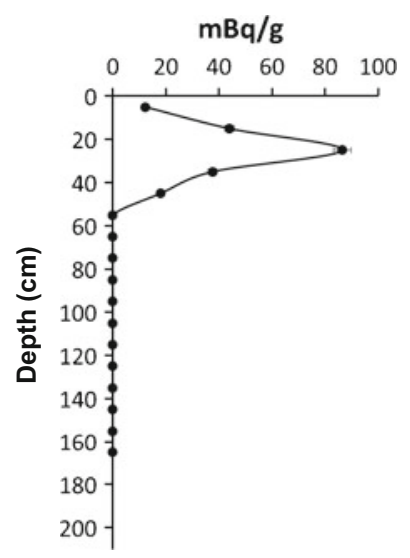

Fig. 5 Distribution of ${ }^{137} \mathrm{Cs}$ activity along the sediment core QN1. The error bars for ${ }^{137} \mathrm{Cs}$ are based on the counting uncertainties. Values under the detection limit $(<10 \mathrm{mBq} / \mathrm{g})$ are presented as 0

$\mathrm{Mn}, \mathrm{Ni}, \mathrm{Pb}, \mathrm{Zn}, \mathrm{OM}$, and clay $(\Phi<2 \mu \mathrm{m})$ and fine $(\Phi<$ $63 \mu \mathrm{m}$ ) fractions], and additionally $\mathrm{Al}$ is a major constituent of some of the most common minerals (i.e., illite, smectite, chlorite, kaolinite, K-feldspar, and plagioclase) in the studied sediments, and thus $\mathrm{Al}$ is considered as a natural geochemical characteristic which is representative for grain size and mineralogical composition and controls the distribution of trace metals in the studied sediments. Furthermore, $\mathrm{Al}$ as well as trace metals are completely released by the sampledigestion technique including hydrofluoric acid (HF) which is also a prerequisite for the normalization to $\mathrm{Al}$ (Schropp and Windom 1988). Therefore, in this study, Al is considered as the most suitable normalizer and consequently the linear regression equations of trace metal versus $\mathrm{Al}$ are constructed based on the database of 57 sediment samples below $36 \mathrm{~cm}$ depth. These trace metal vs. Al relationships are expressed in Fig. 6.

\section{Origin of Trace Metals in Sediment}

The origin of trace metals in the studied sediments was assessed based on a normalization approach (suggested by Schropp and Windom 1988; Loring and Rantala 1992) in which the data from surficial-sediment samples were projected and compared with the regression line and the $95 \%$ prediction interval derived from the linear regression equations of trace metals versus Al (Fig. 6). According to Schropp and Windom (1988) and Loring and Rantala (1992), data points falling inside the $95 \%$ prediction interval would be considered to be part of the natural geochemical population, whereas those outside would be considered to belong to a different or anomalous population.
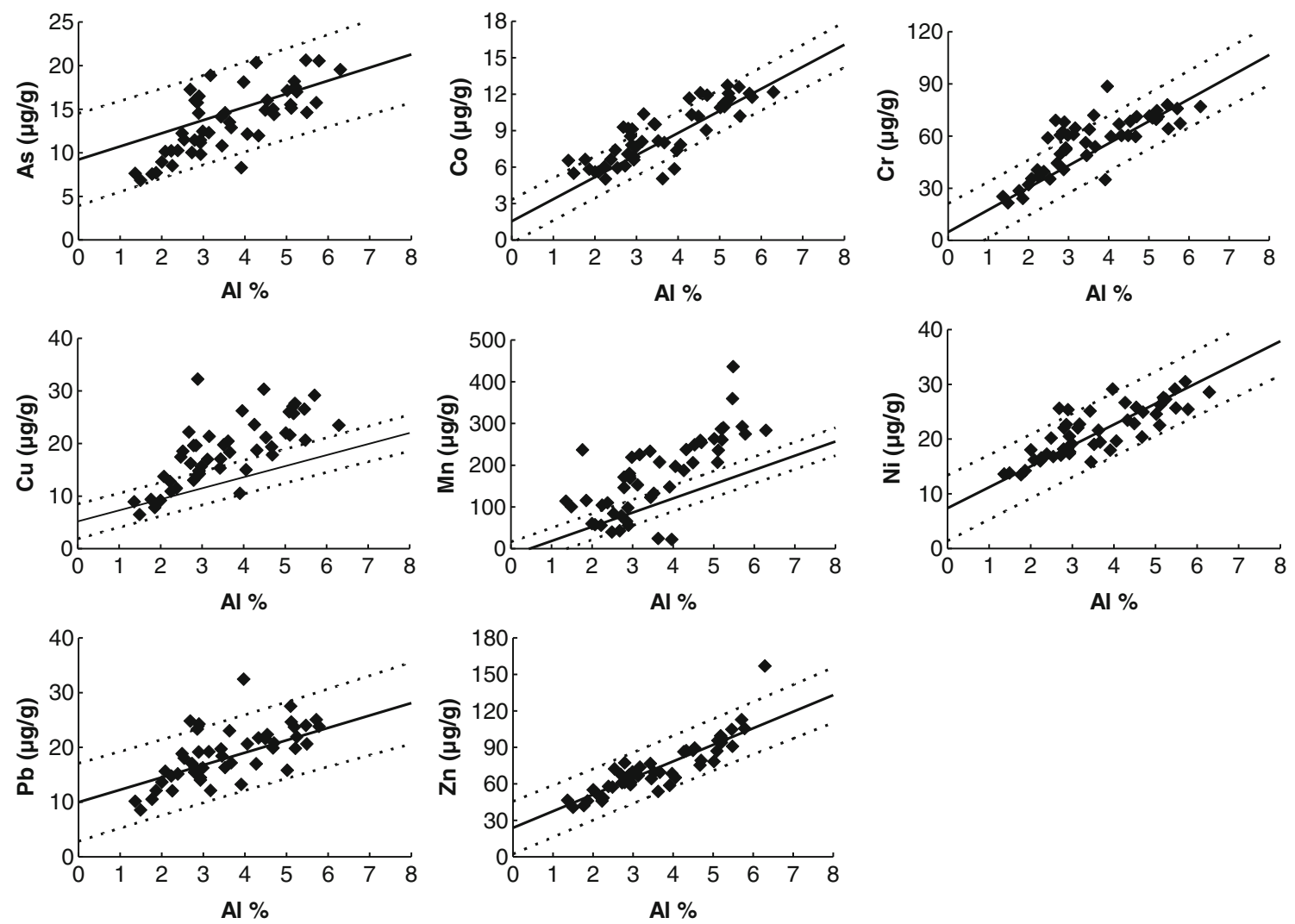

Fig. 6 Projection of surficial sediment samples on the background scatterplot of trace metal vs. Al. The solid and dashed lines are the background regression line and the $95 \%$ prediction band, respectively 
In the studied surficial sediments, almost all the data points for $\mathrm{Co}, \mathrm{Cr}, \mathrm{Ni}, \mathrm{Pb}, \mathrm{Zn}$, and As fall inside the $95 \%$ prediction interval, whereas for $\mathrm{Cu}$ and $\mathrm{Mn}$, some of the points slightly deviate from the $95 \%$ prediction interval. However, for $\mathrm{Mn}$, most of the outliers come from samples from Ha Long Bay where carbonate rocks are the dominant lithology, and for $\mathrm{Cu}$ most of the outliers are related to the samples with high organic matter contents in mangrove areas. Therefore, those outliers are supposed to possibly result from other sources (i.e., Mn-bearing carbonate bedrocks or $\mathrm{Cu}$-rich organic matter) rather than from anthropogenic activities. Moreover, the deviation of the outliers is small, suggesting that the contribution of anthropogenic activities if any is limited (Schropp and Windom 1988). In summary, trace metals are mainly derived from natural bio/ geochemical processes such as the weathering and erosion of bedrocks while the contribution of anthropogenic activities is not considerable.

Referring to previous studies, i.e., Thuc Anh (2006) and Ho et al. (2010) ("Description of the Study Area" section), our findings are not in line with their conclusions, which stated that $\mathrm{Pb}, \mathrm{Cu}$, and $\mathrm{Cr}$ and especially As were contaminated in Ha Long Bay. If the local background levels of trace metals are not determined and the normalization procedure to a reference element is not applied, and if the assessment of the contamination status is only based on the comparison of trace metal concentrations in surficial sediments with the Sediment Quality Guidelines or reference values from the continental crust and sedimentary rocks, the risk of trace metal pollution for Ha Long Bay can be overestimated.

\section{Fractionation and Mobility of Trace Metals in Sediment}

The BCR three-step sequential extraction (Rauret et al. 1999) is widely used to assess the distribution of sediment-associated trace metals among various geochemical phases and evaluate their potential mobility under various environmental conditions (Skvarla 1998; Li et al. 2001). The distribution of trace metals ( $\mathrm{Co}, \mathrm{Cr}, \mathrm{Cu}, \mathrm{Mn}, \mathrm{Ni}, \mathrm{Pb}, \mathrm{Zn}$, and $\mathrm{As}$ ) into four different chemical fractions in the sediment core QN1 is shown in Fig. 7.

Trace metals that are recovered in the acid-soluble fraction can be released as a result of acidification processes in sediments (Zerbe et al. 1999; Li et al. 2001). This fraction represents $11-28 \%$ for $\mathrm{Mn}, 5-18 \%$ for $\mathrm{Co}, 3-15 \%$ for $\mathrm{Zn}$, and $4-8 \%$ for $\mathrm{Ni}$, but is not considerable for $\mathrm{As}, \mathrm{Cr}, \mathrm{Cu}, \mathrm{Pb}$, and $\mathrm{Zn}$. The reducible fraction is high for $\mathrm{Pb}(39-49 \%)$ and Mn (27-40\%), but low for other trace metals $(<20 \%)$. The reducible fraction is related to elements bound to $\mathrm{Fe}$ and $\mathrm{Mn}$ hydr/oxides which are particularly susceptible to alterations in redox conditions. Reducing conditions, which can occur during a high tide period, may cause a release of trace metals (Tack and Verloo 1995; Cappuyns and Swennen 2004). The oxidizable fraction is important for As (10-34\%) and $\mathrm{Cu}$
$(15-32 \%)$, but small for other trace metals $(<25 \%)$. The aerobic or anaerobic oxidation of organic and sulfide matrix may induce the release of trace metals from this fraction to porewater (Zerbe et al. 1999). The residual fraction (in the crystal lattice of minerals) generally dominates for all trace metals (As $=54-82 \%$; $\mathrm{Co}=46-65 \%$; $\mathrm{Cr}=84-90 \%$; $\mathrm{Cu}=$ $57-71 \%$; $\mathrm{Mn}=29-44 \%$; Ni=75-83 \%; $\mathrm{Pb}=39-54 \%$; $\mathrm{Zn}=$ $58-78 \%$ ). This fraction is essentially unavailable for release into the porewater or surface water under the conditions normally encountered in nature (Skvarla 1998; Zerbe et al. 1999). Therefore, the dominance of this fraction implies a low potential mobility of trace metals in sediment (SzarekGwiazda et al. 2011). Moreover, some authors (Tack and Verloo 1995; Zerbe et al. 1999) reported that in a contaminated area, trace metals would display a higher proportion of non-residual (total of acid-soluble, reducible, and oxidizable) fractions (or a lower proportion of the residual fraction) in surficial-sediment layers if compared with deep sediment layers. Therefore, in our study, the unchanged proportion of the residual fraction with depth suggests a natural origin of trace metals in sediments.

Multiple Regression Relationships Between Trace Metals with Reference Elements in Surficial Sediments

As discussed above, trace metals display a natural origin in the surficial sediments of the Cua Luc Estuary and Ha Long Bay. Therefore, apart from the linear regression equations of trace metal versus $\mathrm{Al}$ (as shown in Fig. 6), the multiple regression equations between trace metals with some reference elements such as $\mathrm{Al}, \mathrm{Fe}, \mathrm{Ca}, \mathrm{OM}$, etc. are widely used for assessing natural levels of trace metals in sediments in pollution monitoring and assessment programs (Zhao et al. 2007; Alagarsamy and Zhang 2010). If compared with the linear regression equations of trace metal versus $\mathrm{Al}$, the use of the multiple regression equations of trace metal vs. multielements is more complicated, but more accurate in predicting natural levels of trace metals in sediments. This is explained by the fact that $\mathrm{Al}$ represents only aluminosilicate minerals while other sorbents such as iron hydr/oxides, organic matter, carbonates, etc. also may contain trace metals. Therefore, the multi-element approach that takes into consideration all these trace-metal-bearing sorbents predicts more efficiently the background levels of trace metals if compared with the single-element (e.g., Al) approach.

With this purpose, a multiple linear regression analysis was performed to model the relationships between trace metals with reference elements. $\mathrm{Al}$ is representative for aluminosilicate minerals. Similarly, $\mathrm{Fe}$ and $\mathrm{Ca}$ are not only possible major elements of aluminosilicates but also represent $\mathrm{Fe}$ compounds (e.g., Fe hydr/oxides or sulfides) and carbonates, respectively. Moreover, organic matter is also an important metal-binding phase. Since Al, Fe, and $\mathrm{OM}$ are the geochemical 


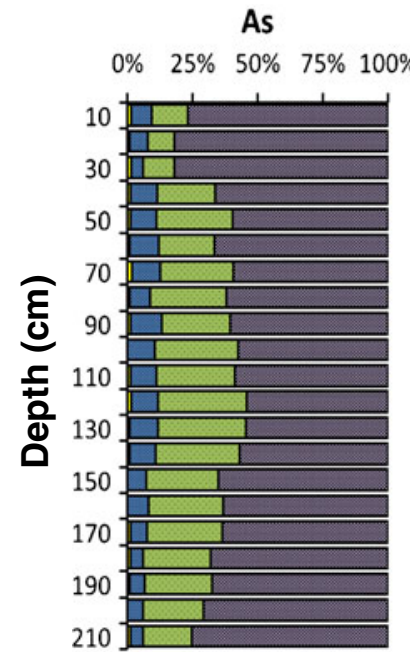

$\mathrm{Mn}$

$\begin{array}{lllll}0 & 25 \% & 50 \% & 75 \% & 100 \%\end{array}$

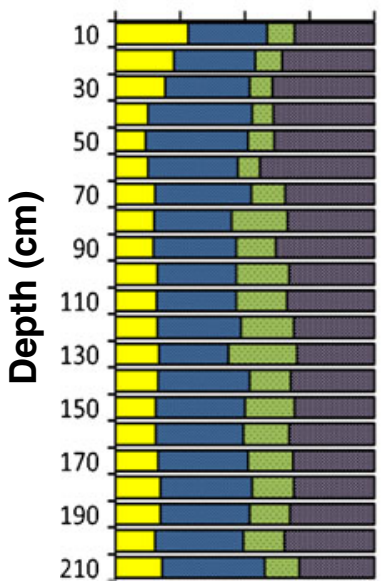

Fig. 7 Distribution of four chemical fractions of trace metals as extracted by the BCR three-step scheme along the sediment core QN1. $\square$ Step 1: acid-soluble fraction (exchangeable and carbonate-

characteristics that control the distribution of $\mathrm{As}, \mathrm{Cr}, \mathrm{Cu}, \mathrm{Ni}$, and $\mathrm{Pb}$ in surficial sediments (refer to "Spatial Distribution of Trace Metals and Controlling Factors" section), they are considered as independent variables for predicting the

$\mathrm{Ni}$
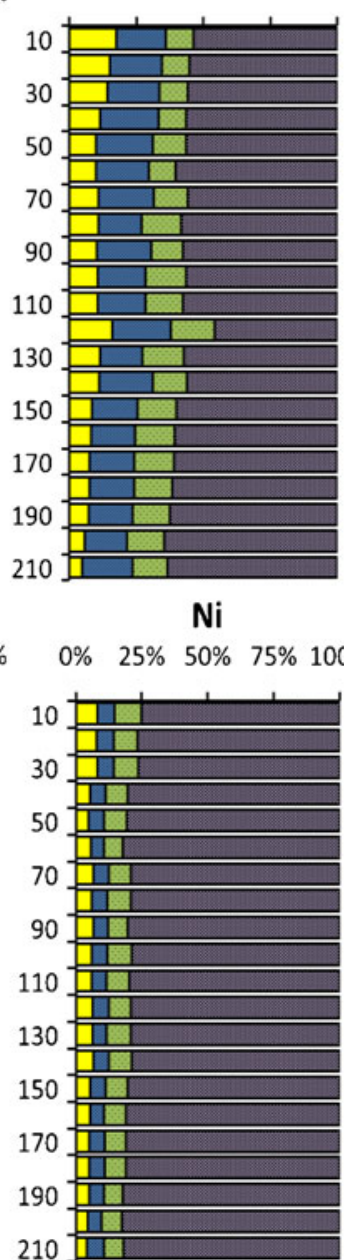

bound). Step 2: reducible fraction (Fe and Mn hydr/oxides-bound) Step 3: oxidizable fraction (organic matter and sulfide-bound). Residual fraction (in the lattice of primary and secondary minerals)

concentrations of these trace metals. In contrast, all $\mathrm{Al}, \mathrm{Ca}$, $\mathrm{Fe}$, and $\mathrm{OM}$ are the independent variables in case of $\mathrm{Mn}, \mathrm{Co}$, and $\mathrm{Zn}$. Generally, all the aforementioned elements display a normal distribution or near normal distribution, so the raw
Table 7 Multiple regression equations of trace metals with sediment properties

\begin{tabular}{lccc}
\hline Equation & $\begin{array}{c}\text { Regression } \\
\text { coefficient }\left(R^{2}\right)\end{array}$ & $\begin{array}{c}\text { Number of } \\
\text { samples }(n)\end{array}$ & $p$ value \\
\hline $\mathrm{As}=0.901+1.139 \mathrm{Al}+0.909 \mathrm{Fe}+2.779 \mathrm{OM}$ & 0.73 & 46 & $<0.00001$ \\
$\mathrm{Cr}=5.229+5.266 \mathrm{Al}+6.755 \mathrm{Fe}+7.123 \mathrm{OM}$ & 0.72 & 49 & $<0.00001$ \\
$\mathrm{Cu}=-0.645+2.612 \mathrm{Al}+0.343 \mathrm{Fe}+3.725 \mathrm{OM}$ & 0.75 & 43 & $<0.00001$ \\
$\mathrm{Ni}=8.379+2.639 \mathrm{Al}+0.022 \mathrm{Fe}+1.463 \mathrm{OM}$ & 0.72 & 49 & $<0.00001$ \\
$\mathrm{~Pb}=3.748+1.446 \mathrm{Al}+1.227 \mathrm{Fe}+3.046 \mathrm{OM}$ & 0.74 & 42 & $<0.00001$ \\
$\mathrm{Mn}=-19.120+31.969 \mathrm{Al}+130.588 \mathrm{Ca}+19.022 \mathrm{Fe}-$ & 0.84 & 41 & $<0.00001$ \\
$21.643 \mathrm{OM}$ & & & \\
$\mathrm{Co}=1.505+0.665 \mathrm{Al}+4.454 \mathrm{Ca}+1.311 \mathrm{Fe}+0.449 \mathrm{OM}$ & 0.73 & 48 & $<0.00001$ \\
$\mathrm{Zn}=13.862+8.977 \mathrm{Al}+48.696 \mathrm{Ca}+6.632 \mathrm{Fe}+1.339 \mathrm{OM}$ & 0.81 & 49 & $<0.00001$ \\
\hline
\end{tabular}


data (without log transformation) from 49 surficial-sediment samples were used for the multiple regression analysis. The "Mahalanobis distances" method was used to eliminate outliers and increase the significance level for the regression equations. The established multiple regression equations are given in Table 7.

\section{Conclusion}

Although trace metals in surficial sediments are generally characterized by higher concentrations in Ha Long Bay if compared to the Cua Luc Estuary, their total concentrations are controlled by the distribution of the fine (clay+silt) fraction, and hence the concentrations of $\mathrm{Al}, \mathrm{Fe}$, and organic matter. Moreover, $\mathrm{Mn}, \mathrm{Co}$, and $\mathrm{Zn}$ are also related to carbonates and $\mathrm{pH}$. The comparison of the normalized (towards $\mathrm{Al}$ ) concentrations of trace metals between the surficial sediments and the subsurface core sediments, in combination with ${ }^{137} \mathrm{Cs}$ dating, indicates that almost all data points fall inside or deviate only slightly from the $95 \%$ prediction interval of the linear regression relationships of trace metal vs. Al, suggesting a natural origin of trace metals in surficial sediments. The operationally defined fractionation by the BCR three-step extraction shows a dominance of the residual fraction (assumed to be present in the lattice of primary and secondary minerals), and this fraction does not change much in recent sediment layers. This implies a low potential mobility and also supports the natural origin of trace metals in surficial sediments. Moreover, the linear regression relationships of trace metal vs. $\mathrm{Al}$ and the multiple regression relationships of trace metal vs. multi-elements $(\mathrm{Al}, \mathrm{Ca}, \mathrm{Fe}$, and $\mathrm{OM}$ ) are also provided for predicting the background concentrations of trace metals in surficial sediments of the area, which is essential information in pollution monitoring and assessment programs in the future.

Acknowledgments We would like to thank Prof. Noel Vandenberghe, Mr. Rieko Adriaens, and Ms. Ria Brepoels from the Division of Applied Geology \& Mineralogy (Department Earth \& Environmental Sciences, KU Leuven) for the grain-size and XRD mineralogical analyses. This research is supported by the Belgian Technical Cooperation (BTC) through a PhD scholarship, and the International Foundation for Science, Stockholm, Sweden and the Organization for the Prohibition of Chemical Weapons, The Hague, The Netherlands, through a grant to Ho Huu Hieu.

\section{References}

Adamo, P., M. Arienzo, M. Imperato, D. Naimo, G. Nardi, and D. Stanzione. 2005. Distribution and partition of heavy metals in surface and subsurface sediments of Naples city port. Chemosphere 61: 800-809.

Alagarsamy, R., and J. Zhang. 2010. Geochemical characterization of major and trace elements in the coastal sediments of India. Environmental Monitoring and Assessment 161(1-4): 161-176.
Batista, M.J., A. Demetriades, S. Pirc, W. De Vos, M. Bidovec, and L. Martins. 2006. Annex 5: Factor analysis interpretation of European soil, stream and floodplain sediment data. In: Geochemical Atlas of Europe, Part 2 (eds. De Vos W. and T. Tarvainen), 567-618. http://www.gtk.fi/publ/foregsatlas/ part2.php. Accessed 25 June 2007.

Cappuyns, V., and R. Swennen. 2004. Secondary mobilisation of heavy metals in overbank sediments. Journal of Environmental Monitoring 6: 434-440.

Cappuyns, V., R. Swennen, and A. Devivier. 2006. Dredged river sediments: potential chemical time bombs? A case study. Water, Air, and Soil Pollution 171: 49-66.

Chen, C.W., C.M. Kao, C.F. Chen, and C.D. Dong. 2007. Distribution and accumulation of heavy metals in the sediments of Kaohsiung Harbor, Taiwan. Chemosphere 66: 1431-1440.

Cong Luong, N. 1980. Geology and mineral resources of Hon GaiMong Cai area at the scale 1/200,000. Department of Geology and Mineral Resources of Vietnam. In Vietnamese.

De Saedeleer, V., V. Cappuyns, W. De Cooman, and R. Swennen. 2010. Influence of major elements on heavy metal composition of river sediments. Geologica Belgica 13(3): 257-268.

Dinelli, E., G. Cortecci, F. Lucchini, and E. Zantedeschi. 2005. Sources of major and trace elements in the stream sediments of the Arno river catchment (northern Tuscany, Italy). Geochemical Journal 39: 531-545.

Ho, H.H., R. Swennen, and A. Van Damme. 2010. Distribution and contamination status of heavy metals in estuarine sediments near Cua Ong Harbor, Ha Long Bay, Vietnam. Geologica Belgica 13(1-2): 37-47.

Huisman, D.J., F.J.H. Vermeulen, J. Baker, A. Veldkamp, S.B. Kroonenberg, and G.Th Klaver. 1997. A geological interpretation of heavy metal concentrations in soils and sediments in the southern Netherlands. Journal of Geochemical Exploration 59: 163-174.

ISO 10390 2005. Soil quality-determination of $\mathrm{pH}$. International Organization for Standardization (ISO).

Jerald, S.L. 1995. Environmental modelling: fate and transport of pollutants in water, air and soil. New York: Wiley.

Karbassi, A.R., and R. Amirnezhad. 2004. Geochemistry of heavy metals and sedimentation rate in a bay adjacent to the Caspian Sea. International Journal of Environmental Science and Technology 1(3): 191-198.

Li, X., Z. Shen, O.W.H. Wai, and Y.S. Li. 2001. Chemical forms of Pb, $\mathrm{Zn}$ and $\mathrm{Cu}$ in the sediment profiles of the Pearl River Estuary. Marine Pollution Bulletin 42(3): 215-223.

Loring, D.H., and R.T.T. Rantala. 1992. Manual for geochemical analyses of marine sediments and suspended particulate matter. Earth-Science Reviews 32: 235-283.

Rauret, G., J.F. López-Sánduz, A. Sahuquillo, R. Rubio, C. Davidson, A. Ure, and Ph Quevauviller. 1999. Improvement of the BCR three-step sequential extraction procedure prior the certification of new sediment and soil reference materials. Journal of Environmental Monitoring 1: 57-60.

Ritchie, J.C., and J.R. McHenry. 1990. Application of radioactive fallout cesium-137 for measuring soil erosion and sediment accumulation rates and patterns: a review. Journal of Environmental Quality 19: 215-233.

Rubio, B., M.A. Nombela, and F. Vilas. 2000. Geochemistry of major and trace elements in sediments of the Ria de Vigo (NW Spain): an assessment of metal pollution. Marine Pollution Bulletin 40 (11): 968-980.

Schropp, S.J., and H.L. Windom. 1988. A guide to the interpretation of metal concentrations in estuarine sediments. Coastal Zone Management Section, Florida Department of Environmental Regulation, 2600 Blairstone Rd., Tallahassee, FL, USA.

Schumacher, B.A. 2002. Methods for the determination of total organic carbon (TOC) in soils and sediments. Office of Research and Development, US Environmental Protection Agency. 
Skvarla, J. 1998. A Study on the trace metal speciation in the Ružín reservoir sediment. Acta Montanistica Slovaca 2: 177-182.

Srodon, J., V.A. Drits, D.K. McCarty, J.C.C. Hsieh, and D.D. Eberl. 2001. Quantitative X-ray diffraction analysis of clay-bearing rocks from random preparations. Clay and Clay Minerals 49(6): 514-528.

Swennen, R., and J. Van Der Sluys. 1998. Zn, Pb, Cu, Cd and As distribution patterns in overbank and medium order stream sediment samples: their use in environmental geochemistry and in exploration of base metal ore bodies in heavily polluted areas. Journal of Geochemical Exploration 65: 27-45.

Szarek-Gwiazda, E., A. Czaplicka-Kotas, and E. Szalinska. 2011. Background concentrations of nickel in the sediments of the Carpathian Dam Reservoirs (Southern Poland). CLEAN—Soil, Air, Water 39(4): 368-375.

Tack, F.M.G., and M.G. Verloo. 1995. Chemical speciation and fractionation in soil and sediment heavy metal analysis: a review. International Journal of Environmental Analytical Chemistry 59: 225-238.

Taylor, S.R., and S.M. McLennan. 1985. The continental crust: its composition and evolution. Oxford: Blackwell.
Taylor, S.R., and S.M. McLennan. 1995. The geochemical evolution of the continental crust. Reviews of Geophysics 33: 241-265.

Thornton, I. 1995. Metals in the global environment: facts and misconceptions. Ottawa: International Council on Metals and the Environment.

Thuc Anh, N.T. 2006. Environmental geochemical characteristics of intertidal sediments in rivermouth areas in Quang Ninh and Haiphong provinces. PhD thesis, Hanoi University of Mining and Geology, Vietnam. In Vietnamese

Turekian, K.K., and K.H. Wedepohl. 1961. Distribution of the elements in some major units of the earth's crust. Geology Society of America Bulletin 72: 175-192.

Wang, F., and J. Chen. 2000. Relation of sediment characteristics to trace metal concentrations: a statistical study. Water Research 34 (2): 694-698.

Zerbe, J., T. Sobczynski, H. Elbanowska, and J. Siepak. 1999. Speciation of heavy metals in bottom sediments of lakes. Polish Journal of Environmental Studies 8(5): 331-339.

Zhao, F.J., S.P. McGrath, and G. Merrington. 2007. Estimates of ambient background concentrations of trace metals in soils for risk assessment. Environmental Pollution 148: 221-229. 
Reproduced with permission of the copyright owner. Further reproduction prohibited without permission. 